\title{
Perlindungan Hukum Terhadap Korban Konflik Sosial
}

\author{
Petrus Soerjowinoto \\ petrus@unika.ac.id \\ Universitas Katolik Soegijapranata, Semarang
}

\begin{abstract}
The fact shows that social conflicts remain frequently happening in Indonesia until today. The social conflicts manifest in various forms and happen in different sites and are caused by various reasons. The motto of Bhinneka Tunggal Ikarepresenting Indonesia as a nation having diversity in tribes, religions, races, and groups is indeed to be a significant factor and capital that contributes to the establishment of a unitary state of the Republic of Indonesia. However, the motto, on the other hand, can also be a seed of the emergence of vertical and horizontal conflicts. It could be noted that there were a lot of serious social conflicts that caused casualties in the forms of death, loss of property, social and environmental damages, human rights violations and so on. As a critical reflection, Indonesian nation is now being faced to challenges that tend to lead to disintegrative and threatening situations that will probably threaten the existence of the nation. Besides, there are a number of sites having potential social conflictsand they spread throughout Indonesia. This needs to be overcome.
\end{abstract}

Keywords: legal protection, victim, social conflict

ABSTRAK: Kenyataan menunjukkan bahwa: di Indonesia sampai saat ini masih sering terjadi konflik sosial dalam berbagai bentuk di berbagai wilayah dengan berbagai sebab. Bhinneka Tunggal Ika yang merupakan keanekaragaman suku, agama, ras dan golongan merupakan modal dan faktor yang memberikan kontribusi tegaknya negara kesatuan Republik Indonesia, namun di sisi lain, sekaligus juga bisa menjadi munculnya konflik vertikal maupun horisontal. Telah dicatat banyak sekali konflik besar yang menimbulkan korban yang berupa: kematian, kerugian harta benda, kerusakan sosial, kerusakan lingkungan, pelanggaran HAM berat dan sebagainya. Refleksi kritis bahwa bangsa Indonesia dihadapkan pada tantangan yang cenderung mengantarkan ke situasi yang bersifat disintegratif dan mengancam eksistensi bangsa, serta terdapat sejumlah titik rawan konflik sosial di Indonesia yang tersebar di seluruh Indonesia yang perlu diatasi.

Kata Kunci: HAM, Konflik Sosial, Perlindungan Hukum

\section{PENDAHULUAN}

\section{LATAR BELAKANG}

Indonesia di bawah pemerintahan orde baru mampu mewujudkan stabilitas ekonomi, stabilitas politik, dan stabilitas keamanan, meskipun pada akhirnya tidak dapat mempertahankannya. Runtuhnya kekuasaan Orde Baru telah mendorong pendulum dari kutub "keterpasungan demokrasi" menuju "kebebasan demokrasi" yang sayangnya tidak didukung dengan "infrastruktur mental" yang kondusif, menjadikan demokrasi mengarah ke anarki. Demokrasi yang "kebablasen” sebagaimana ekses-ekses yang timbul dalam 
pelaksanaan otonomi dan desentralisasi pemerintah daerah semakin hari semakin mengarah ke disintegrasi dan kerancuan dalam memahami arti dan makna identitas nasional.

Identitas Nasional itu merupakan manifestasi nilai-nilai budaya yang sudah tumbuh dan berkembang sebelum masuknya agama-agama besar di Indonesia dalam berbagai aspek kehidupan dari ratusan suku dan bahasa yang kemudian "dihimpun" dalam satu kesatuan Indonesia menjadi kebudayaan nasional dengan acuan Pancasila dan Roh Bhinneka Tunggal Ika sebagai dasar dan arah pengembangannya dalam kehidupan berbangsa dan bernegara ${ }^{52}$.

Bhinneka Tunggal Ika yang merupakan keanekaragaman suku, agama, ras dan golongan di Idonesia merupakan modal dan faktor yang memberikan kontribusi tegaknya negara kesatuan Republik Indonesia. Di sisi lain, keanekaaragaman suku, agama, ras dan golongan sekaligus juga bisa menjadi munculnya konflik vertikal maupun horisontal.

Kemungkinan munculnya konflik akan semakin besar, jika terjadi kesenjangan pembangunan, ketidakadilan, kesenjangan sosial, ekonomi, kemiskinan, dinamika kehidupan politik (idiologi) dan pertahanan keamanan.

Kenyataan yang ada menunjukkan bahwa: di Indonesia sampai saat ini masih sering terjadi konflik sosial dalam berbagai bentuk di berbagai wilayah dengan berbagai sebab. Di dalam sejarah telah dicatat banyak sekali konflik besar yang menimbulkan korban yang berupa: kematian, kerugian harta benda, kerusakan sosial, kerusakan lingkungan, pelanggaran HAM berat, kesengsaraan umat manusia yang sangat luar biasa, hilangnya rasa aman, terciptanya rasa takut, persaaan benci, dendam, dan timbul rasa permusuhan, sehingga menghambat terwujudnya kesejahteraan sosial.

Ide dasar untuk melindungi dan memberikan rasa aman bagi rakyat Indonesia dalam menangani konflik sosial dapat paparkan sebabagi berikut:

Bahwa Negara Kesatuan Republik Indonesia melindungi segenap bangsa dan seluruh tumpah darah Indonesia, memajukan kesejahteraan umum, dan menegakkan hak asasi setiap warga melalui upaya terciptanta suasana yang aman, tentram, tertib, damai, dan sejahtera baik lahir maupun batin sebagai wujud hak setiap orang atas perlindungan agama, diri pribadi, keluarga, kehormatan, martabat dan harta benda.

Bahwa perseteruan dan atau benturan antar kelompok masyarakat dapat menimbulkan konflik sosial yang mengakibatkan terngganggunya stabilitas nasioanl dan terhambatnya pembangunan nasioana ${ }^{53}$.

Pada saat ini pemerintah sudah mengundangkan Peraturan Pemerintan No 2 tahun 2015 tentang Peraturan pelaksanaan Undang-undang No 7 Tahun 2012 tentang Penganan konflik Sosial. Peraturan tersebut diharapkan dapat melindungi dan memberikan rasa aman

52 Soerjowinoto, Petrus, 2014, Pendidikan Kewarganegaraan Buku Panduan Mahasiswa, Semarang: PPMKU Unika Soegijapranata, hal 3.

53 Lihat konsideran bagian menimbang butir a dan butir b Undang-undang Republik Indonesia Nomor 7 Tahun 2012 Tentang Penanganan Konflik Sosial, Lembaran Negara Republik Indonesia tahun 2012 Nomor 116. 
bagi masyarakat secara optimal serta penanganan konflik sosial secara komprehensif, terkoordinasi, dan terintegrasi.

Bersumber pada berkembangnya proses globalisasi yang melahirkan neoliberalisme dan kapitalisme, implikasinya adalah: tumbuhnya tata sosial baru. Fenomena globalisasi yang melahirkan neoliberalisme dan kapitalisme menimbulkan keterkaitan dan juga saling berkepentingan yang menembus batas-batas geografis suatu negara. Globalisasi melahirkan interdependensi namun tidak akan menciptakan integrasi dalam bidang sosial dan politik, ekonomi, keamanan dll.

Meningkatnya konflik sosial pasca reformasi merupakan konsekuensi logis dari runtuhnya kekuasaan Orde Baru selama 32 tahun yang menegakkan persatuan dan kesatuan bangsa melalui pendekatan keamanan dan memasung hak-hak konstitusional rakyat melalui berbagai kebijaksanaan yang bertentangan dengan konstitusi ${ }^{54}$. Kini yang kita rasakan adalah: berkembangnya suasana kecurigaan disertai hilangnya kepercayaan (trust) antar sesama baik vertikal maupun horisontal, sejalan dengan semakin menjalarnya konflik sosial.

Terkait dengan uraian di atas, konflik sosial yang pernah terjadi di Indonesia seperti misalnya: peristiwa G30S/PKI, Tanjung Priok, Timor-timur, kasus Ambon, Poso, Aceh, pontianak, Sampit, Lampung dan lain-lain juga menimbulkan korban, sehingga menghambat terwujudnya kesejahteraan sosial yang perlu mendapatkan perlindungan hukum.

Tantangan terhadap munculnya konflik sosial perlu di refleksikan secara kritis bahwa bangsa Indonesia dihadapkan pada tantangan yang cenderung mengantarkan ke situasi yang bersifat disintegratif dan mengancam eksistensi bangsa dan negara kesatuan yang berdasar ideologi Pancasila, serta terdapat sejumlah titik rawan konflik sosial di Indonesia yang tersebar di seluruh Indonesia.

\section{PERUMUSAN MASALAH}

Berdasarkan uraian di atas, tulisan ini akan memaparkan dua hal yaitu:

1. Bagaimana pengaturan dalam menangani konflik sosial?

2. Bagaimana perlindungan korban akibat terjadinya konflik sosial?

\section{PEMBAHASAN}

\section{A. PENGATURAN MENANGANI KONFLIK SOSIAL.}

"Konflik sosial adalah perseteruan dan atau benturan fisik dengan kekerasan anatara dua kelompok masyarakat atau lebih yang berlangsung dalam waktu tertentu dan berdampak luas yang mengakibatkan ketidakamanan dan disintegrasi sosial sehinggan mengganggu stabilitas nasional dan menghambat pembangunan nasional ${ }^{55 "}$.

Keanekaragaman suku, agama, ras, dan budaya Indonesia dengan jumlah penduduk lebih dari 240 juta jiwa, pada satu sisi merupakan suatu kekayaan bangsa yang secara langsung ataupun tidak langsung dapat memberikan kontribusi positif bagi upaya

54 Soerjowinoto, Petrus, Ibid, hal 7

55 Pasal 1 butir 1 Undang-undang Nomor 12 Tahun 2012 tentang penanganan Kondflik. 
menciptakan kesejahteraan masyarakat. Namun pada sisi lain, kondisi tersebut dapat membawa dampak buruk bagi kehidupan nasional apabila terdapat ketimpangan pembangunan, ketidakadilan dan kesenjangan sosial dan ekonomi, serta ketidakterkendalian dinamika kehidupan politik.

Kerugian berupa harta benda kiranya sulit untuk dapat dihitung, mengingat bahwa konflik sosial yang ada, dilakukan dengan persenjataan yang akan mengakibatkan malapetaka yang lebih besar. Berdasarkan pernyataan tersebut, maka tidaklah mengherankan Indonesia berusaha sekuat tenaga untuk meniadakan konflik sosial, atau sekurang-kurangnya memperkecil terjadinya konflik sosial.

Ketentuan-ketentuan yang menangani konflik sosial yang sudah ada (tertulis maupun tidak tertulis) perlu disosialisasikan, dan juga perlu secara terus-menerus dikembangkan dalam hukum nasional, serta dikaji guna untuk melindungi korban, terutama pada kelompok masyarakat sipil yang tidak berkonflik dengan kelompok masyarakat manapun.

Hukum perang mengatur dalam hal bagaimana negara dibenarkan menggunakan senjata (jus ad bellum) dan hukum yang berlaku dalam perang (jus in bello). Hukum yang berlaku dalam jus in bello ini dibagi menjadi dua yaitu : (1) yang mengatur cara dilakukannya perang (conduuct of war) dan (2) yang mengatur perlindungan orang-orang yang menjadi korban perang ${ }^{56}$.

Di dalam US Army Field Manual of the law of Landwarfore dijelaskan ada beberapa tujuan hukum perang yaitu :

a. Melindungi baik kombatan maupun non kombatan dari penderitaan yang tidak perlu;

b. Menjamin hak asasi tertentu dari orang yang jatuh ke tangan musuh;

c. Memungkinkan dikembangkannya perdamaian;

d. Membatasi kekuasaan fihak berperang ${ }^{57}$.

Ketentuan-ketentuan tersebut masih berupa ketentuan intenasional, kiranya akan timbul kesulitan jika diterapkan di dalam hukum nasional, secara khusus untuk menangani konflik sosial di dalam suatu negara.

Indonesia, kini telah memiliki Undang-undang tentang penanganan konflik, yaitu Undang-undang No 7 Tahun 2012, di sisi yang lain pada tanggal 2 Februari 2015 yang lalu telah diundangkan peraturan pelaksananya yaitu: Peraturan Pemerintah No 2 tahun 2015 tentang peraturan pelaksanaan Undang-undang No 7 tahun 2012, namun demikian implementasinya belum sepenuhnya seperti yang diharapkan.

Asas, Tujuan, dan Ruang Lingkup sebagaimana yang dipaparkan dalam Pasal 2 Undang-undang Nomor 7 tahun 2012 penanganan konflik sosial mencerminkan sebagai berikut:

a. kemanusiaan;

b. hak asasi manusia;

c. kebangsaan;

${ }^{56}$ GPH. Haryomataram, Brigjen TNI-AD (Purn), 1984, Hukum Humaniter, Jakarta : CV Rajawali, hal 2-3.

57 Ibid, hal 3 
d. kekeluargaan;

e. kebhinneka-tunggal-ikaan;

f. keadilan;

g. kesetaraan gender;

h. ketertiban dan kepastian hukum;

i. keberlanjutan;

j. kearifan lokal;

k. tanggung jawab negara;

I. partisipatif;

m. tidak memihak; dan

n. tidak membeda-bedakan ${ }^{58}$.

Berdasarkan Undang-undang No 7 Tahun 2012, ruang lingkup penanganan konflik sosial meliputi: pertama Pencegahan Konflik, kedua Penghentian Konflik, dan ketiga Pemulihan Pascakonflik sebabagi berikut ${ }^{59}$.

a. Pencegahan Konflik dilakukan oleh dilakukan oleh Pemerintah, Pemerintah Daerah, dan masyarakat yang meliputi: (a) memelihara kondisi damai dalam masyarakat; (b) mengembangkan sistem penyelesaian perselisihan secara damai; (c) meredam potensi Konflik; dan (d) membangun sistem peringatan dini.

b. Penghentian konflik dilakukan melalui: (a) penghentian kekerasan fisik; (b) penetapan Status keadaan konflik; (c) tindakan darurat penyelamatan dan pelindungan korban; dan atau (d) bantuan penggunaan dan pengerahan kekuatan TNI.

c. Pemulihan Pasca Konflik dilakukan oleh : Pemerintah dan Pemerintah Daerah berkewajiban melakukan upaya Pemulihan Pascakonflik secara terencana, terpadu, berkelanjutan, dan terukur, upaya Pemulihan Pascakonflik meliputi: (a) rekonsiliasi (b) rehabilitasi dan (c) rekonstruksi.

Status Keadaan Konflik berada pada keadaan tertib sipil sampai dengan darurat sipil sebagaimana dimaksud dalam Undang-undang Nomor 23 Prp Tahun 1959. Selanjutnya, Penanganan Konflik pada pascakonflik, Pemerintah dan Pemerintah Daerah berkewajiban melakukan upaya Pemulihan Pascakonflik secara terencana, terpadu, berkelanjutan, dan terukur melalui upaya rekonsiliasi; rehabilitasi; dan rekonstruksi. Undang-undang ini juga mengatur mengenai peran serta masyarakat dan pendanaan Penanganan Konflik.

Tujuan Penanganan konflik sosial untuk:

a. menciptakan kehidupan masyarakat yang aman, tenteram, damai, dan sejahtera;

b. memelihara kondisi damai dan harmonis dalam hubungan sosial kemasyarakatan;

c. meningkatkan tenggang rasa dan toleransi dalam kehidupan bermasyarakat dan bernegara;

58 Pasal 2 Pndang-undang Nomor 7 Tahun 2012 tentang Penanganan Konflik Sosial

59 Pasal 4 Undang-undang Nomor 7 Tahun 2012 tentang Penanganan Konflik Sosial. 
d. memelihara keberlangsungan fungsi pemerintahan;

e. melindungi jiwa, harta benda, serta sarana dan prasarana umum;

f. memberikan pelindungan dan pemenuhan hak korban; dan

g. memulihkan kondisi fisik dan mental masyarakat serta sarana dan prasarana umum ${ }^{60}$.

Di dalam penjelasan umum Undang-undang Nomor 7 tahun 2012 dinyatakan bahwa berbagai upaya Penanganan Konflik terus dilakukan berdasarkan peraturan Konflik yang dikembangkan oleh Pemerintah, kerangka regulasi yang ada mencakup tiga strategi sebagai berikut:

1. Kerangka regulasi dalam upaya Pencegahan Konflik seperti regulasi mengenai kebijakan dan strategi pembangunan yang sensitif terhadap Konflik dan upaya Pencegahan Konflik.

2. Kerangka regulasi bagi kegiatan Penanganan Konflik pada saat terjadi Konflik yang meliputi upaya penghentian kekerasan dan pencegahan jatuhnya korban manusia ataupun harta benda.

3. Kerangka regulasi bagi penanganan pascakonflik, yaitu ketentuan yang berkaitan dengan tugas penyelesaian sengketa/proses hukum serta kegiatan pemulihan, reintegrasi, dan rehabilitasi. Kerangka regulasi yang dimaksud adalah segala peraturan perundang-undangan, baik yang tertuang dalam Undang-Undang Dasar Negara Republik Indonesia Tahun 1945 maupun dalam peraturan perundang-undangan yang lain, termasuk di dalamnya Ketetapan Majelis Permusyawaratan Rakyat (TAP MPR) ${ }^{61}$.

Diundangkannya Peraturan Pemerintah Nomor 12 tahun 2015 yang merupakan peraturan pelaksana Undang-undang Nomor 7 Tahun 2012 tentang Penanganan Konflik Sosial.

Ada 4 (empat) materi yang diatur dalam Peraturan Pemerintah tersebut yaitu:

a. Tindakan darurat penyelamatan dan pelindungan korban;

b. Bantuan penggunaan kekuatan TNI;

c. Peran serta masyarakat dalam penanganan Konflik; dan

d. Perencanaan, penganggaran, penyaluran, penatausahaan, pelaporan, dan pertanggungjawaban pengelolaan pendanaan penanganan Konflik.

Peraturan Pemerintah ini disusun sebagai peraturan pelaksana penanganan konflik sosial secara lebih rinci dan operasional yang bertujuan untuk:

a. menciptakan kehidupan masyarakat yang aman, tenteram, damai, dan sejahtera;

b. memelihara kondisi damai dan harmonis dalam hubungan sosial kemasyarakatan;

c. meningkatkan tenggang rasa dan toleransi dalam kehidupan bermasyarakat dan bernegara;

60 Pasal 3 Undang-undang Nomor 7 Tahun 2012 tentang Penanganan Konflik Sosial

${ }^{61}$ Penjelasan umum Undang-undang Nomor 12 tahun 2012 tentang penanganan konflik sosial. 
d. memelihara keberlangsungan fungsi pemerintahan;

e. melindungi jiwa, harta benda, serta sarana dan prasarana umum;

f. memberikan pelindungan dan pemenuhan hak korban; dan

g. memulihkan kondisi fisik dan mental masyarakat serta sarana dan prasarana umum.

Secara umum materi muatan ini mencakup beberapa substansi pokok, antara lain mengenai pencegahan konflik, tindakan darurat penyelamatan dan pelindungan korban, bantuan penggunaan dan pengerahan kekuatan TNI, pemulihan pascakonflik, peran serta masyarakat, pendanaan penanganan konflik, serta monitoring dan evaluasi. Dalam Peraturan Pemerintah ini diatur mengenai kegiatan pencegahan konflik yang memang tidak diamanatkan secara tegas dalam Undang-undang Nomor 7 Tahun 2012 tentang Penanganan Konflik Sosial tetapi dibutuhkan pengaturannya dalam Peraturan Pemerintah ini agar pelaksanaan pencegahan konflik dapat dilaksanakan di lapangan.

Melalui peraturan ini, pemerintah pusat dan pemerintah daerah diberikan kewenangan untuk melaksanakan pencegahan konflik melalui penyelenggaraan kegiatan :

1. penguatan kerukunan umat beragama;

2. peningkatan forum kerukunan masyarakat;

3. peningkatan kesadaran hukum;

4. pendidikan bela negara dan wawasan kebangsaan;

5. sosialisasi peraturan perundang-undangan;

6. pendidikan dan pelatihan perdamaian;

7. pendidikan kewarganegaraan;

8. pendidikan budi pekerti;

9. penelitian dan pemetaan wilayah potensi Konflik dan/atau daerah Konflik;

10. penguatan kelembagaan dalam rangka sistem peringatan dini;

11. pembinaan kewilayahan;

12. pendidikan agama dan penanaman nilai-nilai integrasi kebangsaan;

13. pPenguatan/pengembangan kapasitas (capacity building);

14. pengetasan kemiskinan;

15. desa berketahanan sosial;

16. penguatan akses kearifan lokal;

17. penguatan keserasian sosial; dan

18. bentuk kegiatan lain sesuai dengan ketentuan peraturan perundang-undangan

Selain itu dalam melakukan pencegahan konflik, pemerintah dan pemerintah daerah harus mengoptimalkan penyelesaian perselisihan secara damai melalui musyawarah mufakat dengan melibatkan tokoh masyarakat seperti tokoh agama, tokoh adat dan atau unsur masyarakat lainnya termasuk pranata adat dan pranata sosial. 
Peraturan Pemerintah ini pun mengatur keterlibatan TNI dalam penanganan konflik sosial. Bantuan penggunaan dan pengerahan kekuatan TNI untuk penghentian konflik dilaksanakan setelah adanya penetapan status keadaan konflik oleh pemerintah daerah atau pemerintah. Bantuan penggunaan dan pengerahan kekuatan TNI dilakukan untuk menghentikan kekerasan fisik, melaksanakan pembatasan dan penutupan kawasan konflik untuk sementara waktu.

\section{B. PERLINDUNGAN KORBAN AKIBAT TERJADINYA KONFLIK}

Korban dapat dilihat berbagai sudut pandang: pertama Korban adalah orang yang mengalami penderitaan karena suatu hal yang dimaksud dengan sesuatu hal, disini dapat meliputi perbuatan orang, institusi atau lembaga dan struktur. Kedua Siapa yang menjadi korban, yang dapat menjadi korban tidak hanya manusia tetapi dapat pula korporasi, Negara, asosiasi, keamanan, kesejahteraan umum, agama.

Ada tiga faktor yang menjadi sebab terjadinya korban yaitu:

1. Faktor personal: termasuk keadaan biologis yaitu: usia, jenis kelamin, keadaan mental. Keadaan psikologis yaitu: Agresivitas, kecerobohan, keterasingan.

2. Faktor Sosial: misalnya imigran, kelompok minoritas, pekerjaan, perilaku jahat, hubungan antar pribadi.

3. Faktor situasional: misalnya situasi konflik, tempat dan waktu.

Pengertian korban Konflik sosial adalah individu dan/atau sekelompok orang yang cidera atau meninggal dan yang terancam jiwanya akibat Konflik ${ }^{62}$.

Untuk mendapatkan pemahaman yang lebih baik tentang perlunya perlindungan korban akibat konflik sosial kiranya perlu dilakukan Refleksi secara Ilmiah yang mendalam, sehingga akan mendapatkan dasar-dasar pemikiran perlindungan hukum terhadap individu atau kelompok sebagai korban konflik sosial. Beberapa dasar refleksi pemikiran untuk mendapatkan perlindungan hukum sebagai berikut:

1. Pada hakikatnya Ketentuan-ketentuan pengaturan tentang konflik sosial yang sudah ada (tertulis maupun tidak tertulis) sedikit banyak mengatur nasip hidup manusia. Citra manusia dan kemanusiaan merupakan suatu kemutlakan yang harus dilindungi dan dihormati oleh negara tertutama penghormatan terhadap harkat dan martabat manusia, karena itu mendorong untuk memperjuangkan dan memberikan perlindungan hukum demi perlakuan yang adil.

2. Segala sesuatu termasuk konflik sosial harus diamati secara meluas dan terpadu, suatu hasil interrelasi antara fenomena yang ada dengan faktor-faktior yang saling mempengaruhi. Jadi dalam masalah konflik sosial ini akan diperhatikan dan diperhitungkan pihak-pihak yang melakukan interaksi pemahaman dan pengakuan

62 Pasal 1 butir 5 Peraturan Pemerintah Nomor: 2 tahun 2015 tentang peraturan pelaksanaan Undang-Undang Nomor 7 tahun 2012 tentang Penanganan konflik sosial 
secara interdisipliner, interaksioner dan interdepartemental. Konflik Sosial adalah masalah yang kompleks maka harus didekati secara interdisipliner.

3. Konflik sosial adalah masalah manusia yang merupakan suatu kenyataan sosial, karena itu korban konflik sosial mempunyai aspek-aspek mental, fisik dan sosial. Beberapa unsur sosial dan tindakan individual tertentu maupun kelompok yang mengakibatkan terjadinya konflik sosial selalu dipengaruhi oleh struktur sosial tertentu antara lain :
a. Kepentingan;
b. Lembaga-lembaga sosial;
c. Nilai-nilai sosial;
d. Status dan peran individu maupun kelompok.

4. Dalam rangka memberikan pelayanan terhadap korban konflik sosial perlu diperhatikan dan dimanfaatkan pandangan-pandangan Ilmu tentang korban (viktimologi) sebagai dasar orang bersikap dan bertindak melakukan pelayanan korban konflik sosial tersebut. Pada hakikatnya mempelajari:

a. Siapa itu korban dan yang menimbulkan korban.

b. Apa arti korban konflik sosial bagi mereka yang terlihat dalam proses konflik sosial, maka akan diperoleh sumbangan dalam pengertian yang lebih baik tentang korban akibat konflik sosial yang menimbulkan penderitan mental,fisik, sosial.

c. Untuk memberikan penjelasan tentang kedudukan dan peran korban.

d. Memperhatikan permasalahan korban yang tidak langsung. Misalnya efek politik pada penduduk akibat terjadinya konflik sosial, dan akibat sosial pada setiap orang.

Berdasakan uraian tersebut di atas, pemerintah telah mengundangkan Undangundang No 7 tahun 2012 tentang konflik sosial dan juga telah mengundangkan peraturan pelaksanaanya. Diundangkannya Peraturan Pemerintah Nomor: 2 tahun 2015 tentang Peraturan Pelaksanaan Undang-undang Nomor 7 tahun 2012 tentang Penanganan Konflik Sosial. Peraturan pelaksanaan tentang penanganan konflik sosial ini menunjukan sikap pemerintah adanya political will pemerintah untuk memberikan perlindungan korban kepada rakyat. Peraturan pemerintah No 2 tahun 2015 dalam memberikan perlindungan terhadap korban akibat konflik sosial bertujuan untuk:

a. menciptakan kehidupan masyarakat yang aman, tenteram, damai, dan sejahtera;

b. memelihara kondisi damai dan harmonis dalam hubungan sosial kemasyarakatan;

c. meningkatkan tenggang rasa dan toleransi dalam kehidupan bermasyarakat dan bernegara;

d. memelihara keberlangsungan fungsi pemerintahan;

e. melindungi jiwa, harta benda, serta sarana dan prasarana umum;

f. memberikan pelindungan dan pemenuhan hak korban; dan

g. memulihkan kondisi fisik dan mental masyarakat serta sarana dan prasarana umum. Sebagaimana yang telah dipaparkan di atas Peraturan Pemerintah Nomor 2 Tahun 
2015 ini memberikan amanat sebagai berikut:

h. Tindakan darurat penyelamatan dan pelindungan korban, meliputi (1) meminimalisir jumlah korban, (2) memberikan Rasa aman, (3) menghilangkan truama, dan (4) memberikan layanan yang dibutuhkan bagi korban,

i. Bantuan penggunaan kekuatan TNI, Bantuan penggunaan dan pengerahan kekuatan TNI untuk penghentian Konflik dilaksanakan setelah adanya penetapan status keadaan Konflik oleh pemerintah daerah atau Pemerintah dilakukan untuk:

1) menghentikan kekerasan fisik;

2) melaksanakan pembatasan dan penutupan kawasan Konflik untuk sementara waktu;

3) melaksanakan upaya pembatasan orang di luar rumah untuk sementara waktu;

4) melaksanakan upaya pelarangan orang untuk memasuki kawasan Konflik atau keluar dari kawasan Konflik Untuk Semengtara waktu

5) Mengamankan objek vital nasional dan daerah serta sarana dan prasarana vital yang dimungkinkan menjadi sasaran massa;

6) penyelamatan, evakuasi, dan identifikasi Korban Konflik;

7) pelindungan terhadap kelompok rentan;

8) upaya sterilisasi tempat yang rawan Konflik; dan

9) penyelamatan jiwa raga dan harta benda Korban Konflik.

j. Peran serta masyarakat dalam penanganan Konflik, yaitu Masyarakat dapat berperan serta dalam penanganan Konflik meliputi: (1) pencegahan konflik, (2) penghentian konflik dan (3) pemulihan pasca konflik. Peran serta dapat dilaksanakan oleh: (1) tokoh agama, (2)( tokoh adat, (3) Tokoh Masyarakat, (4) pranata adat, dan (5) pranata sosial. Peran serta masyarakat ini berupa: (1) Pembiayaan, (2) Bantuan Teknis, (3) Penyediaan kebutuhan dasar bagi korban konflik dab (4) bantuan tenaga dan pikiran.

k. Pendanaan penanganan Konflik menjadi tanggung jawab Pemerintah dan pemerintah daerah sesuai dengan kewenangannya, sedangkan perencanaan, penganggaran, penyaluran, penatausahaan, pelaporan, dan pertanggungjawaban pengelolaan pendanaan penanganan Konflik yang bersumber dari APBN atau APBD pada tahap pencegahan Konflik dilakukan sesuai dengan ketentuan peraturan perundang-undangan.

Di sisi lain, tindakan darurat penyelamatan perlindungan korban yang dilakukan pemerintah dan pemerintah daerah meliputi sejumlah tindakan.

a. Penyelamatan, evakuasi, dan identifikasi korban konflik;

b. Pemenuhan kebutuhan dasar korban konflik;

c. Pemenuhan kebutuhan dasar pengungsi, termasuk kebutuhan spesifik perempuan, anak-anak, dan kelompok orang yang berkebutuhan khusus;

d. Perlindungan terhadap kelompok rentan; 
e. Sterilisasi tempat yang rawan konflik;

f. Penegakan hukum; dan

g. Penyelamatan harta benda korban.

Dewasa ini jumlah konflik sosial yang terjadi di dalam negeri menunjukkan peningkatan yang signifikan, pada tahun 2012 terjadi konflik sebabyak 128 kasus meningkat meningkat menjadi $39,27 \%$ dari 77 kasus pada tahun $2012^{63}$, menurut data kementrian sosial terdapat 189 kasus titik rawan konflik sosial di Indonesia. Konflik yang terkait adalah isue tentang agama dan etnis yang mendominasi, ada pula konflik yang bersifat politis seperti isue spasratisme yang terjadi di Aceh, Papua. Konflik lain seperti Lampung (mesuji dan sidomulyo), Jayapura, Timika, Sumbawa dan daerah-daerah lain dilihat sebagai ekpresi rasa kecewa/frustasi sosial, dan kemudian memunculkan kerusuhan masa, yang disebabkan oleh hasutan, caci maki, pembunuhan, perkosaan, pembakaran, perampasan dan pengusiran di akar rumput.

Terhadap konflik-konflik yang terjadi dan dikualifikasikan melakukan pelanggaran HAM berat seperti misalnya kasus G 30 S/PKI, Kasus Tanjung Priok, Talangsari dan lain-lain penegakaan hukumnya dapat diinsersikan melalui Undang-undang No 26 Tahun 2000 tentang Pengadilan HAM. Sampai sekarang penyelesaian terhadap kasus-kasus pelanggaran HAM berat belum terselesaikan dengan baik ${ }^{64}$.

Disisi yang lain, dalam memberikan perlindungan terhadap korban dalam Undang-undang No 26 Tanun 2000 tentang pengadilan HAM telah diatur juga tentang perlindungan korban dan saksi, sebagaimana yang dipaparkan dalam Pasal 34 UU No 26 Th 2000 Tentang Pengadilan HAM sebagai berikut:

(1) Setiap korban dan saksi dalam pelangaran HAM yang berat berhak atas atas perlindungan fisik dan mental dari ancaman, gangguan, teror, dan kekerasan dari pihak manapun.

(2) Perlindungan wajib dilaksanakan oleh aparat penegak hukum dan aparat keamanan secara cuma-cuma ${ }^{65}$.

Untuk melindungi kepentingan korban ditetapkan kompensasi, restitusi, dan rehabilitasi. Setiap korban dan saksi dalam pelanggaran hak asasi manusia yang berat dan atau ahli warisnya dapat memperoleh kompensasi, restitusi, dan rehabilitasi. Kompensasi, restitusi, dan rehabilitasi sebagaimana dimaksud seperti tersebut di atas dicantumkan dalam amar putusan Pengadilan HAM, dan ketentuan mengenai kompensasi, restitusi dan rehabilitasi diatur lebih lanjut dengan peraturan pemerintah.

Kompensasi adalah ganti kerugian yang diberikan oleh negara, karena pelaku tidak mampu memberikan ganti kerugian sepenuhnya yang menjadi tanggung jawabnya.

\footnotetext{
${ }^{63}$ Suharyono, 2013, Penegakan Hukum di daerah Konflik, pusat penelitian dan pengembangan sistem hukum nasional badan pembinaan hukum kementrian hukum dan HAM Republik Indonesia.

${ }^{64}$ Dalam pidato kenegaraan Presiden Joko Widodo pada tanggal 14 Agustus 2015 yang lalu masih dipikirkan jalan keluarnya.

${ }^{65}$ Pasal 34 Undang-undang Nomor 26 Tahun 2000 tentang Pengadilan HAM
} 
Restitusi adalah ganti kerugian yang diberikan kepada korban atau keluarganya oleh pelaku atau pihak ketiga, restitusi berupa :

a. pengembalian harta milik;

b. pembayaran ganti kerugian untuk kehilangan atau penderitaan; atau

c. penggantian biaya untuk tindakan tertentu.

Rehabilitasi adalah, pemulihan pada kedudukan semula, misalnya kehormatan, nama baik, jabatan, atau hak-hak lain.

Dalam pemulihan pasca konflik Undang-undang Nomor 7 tahun 2012 mengatur tentang (1) rekonsiliasi, (2) rehabilitasi dan (3) rekontruksi. Pemerintah dan pemerintah daerah berkewajiban melakukan upaya pemulihan pasca konflik secara terencana, terpadu, berkelanjutan, dan terukur.

1. Rekonsiliasi dilakukan oleh Pemerintah dan Pemerintah Daerah antara para pihak dengan cara:

a. perundingan secara damai,

b. pemberian Restitusi dan atau

c. pemaafan.

Rekonsiliasi dilakukan dengan Pranata Adat dan/atau Pranata Sosial atau Satuan Tugas konflik Sosial.

2. Rehabilitasi dilaksanakan oleh pemerintah dan pemerintah daerah di daerah pascakonflik dan daerah terkena dampak Konflik sebagaimana dimaksud dalam Pasal 36 ayat (2) huruf b, sesuai dengan tugas, tanggung jawab, dan wewenangnya.

Pelaksanaan rehabilitasi sebagaimana dimaksud pada ayat (1) meliputi:

1. pemulihan psikologis korban Konflik dan pelindungan kelompok rentan;

2. pemulihan kondisi sosial, ekonomi, budaya, keamanan, dan ketertiban;

3. perbaikan dan pengembangan lingkungan dan/atau daerah perdamaian;

4. penguatan relasi sosial yang adil untuk kesejahteraan masyarakat;

5. penguatan kebijakan publik yang mendorong pembangunan lingkungan dan/atau daerah perdamaian berbasiskan hak masyarakat;

6. pemulihan ekonomi dan hak keperdataan, serta peningkatan pelayanan pemerintahan;

7. pemenuhan kebutuhan dasar spesifik perempuan, anak-anak, lanjut usia, dan kelompok orang yang berkebutuhan khusus;

8. pemenuhan kebutuhan dan pelayanan kesehatan reproduksi bagi kelompok perempuan;

9. peningkatan pelayanan kesehatan anak-anak; dan

10. pemfasilitasian serta mediasi pengembalian dan pemulihan aset korban Konflik. 
3. Rekontruksi. dilaksanakan oleh Pemerintah dan Pemerintah Daerah sesuai dengan tugas, tanggung jawab, dan wewenangnya, pelaksanaan rekonstruksi meliputi:

a. pemulihan dan peningkatan fungsi pelayanan publik di lingkungan dan/atau daerah pascakonflik;

b. pemulihan dan penyediaan akses pendidikan, kesehatan, dan mata pencaharian;

c. perbaikan sarana dan prasarana umum daerah Konflik;

d. perbaikan berbagai struktur dan kerangka kerja yang menyebabkan ketidaksetaraan dan ketidakadilan, termasuk kesenjangan ekonomi;

e. perbaikan dan penyediaan fasilitas pelayanan pemenuhan kebutuhan dasar spesifik perempuan, anak-anak, lanjut usia, dan kelompok orang yang berkebutuhan khusus;

f. perbaikan dan pemulihan tempat ibadah.

Konflik sosial kasus bentrok di kabupaten Talikara, Papua pada tanggal 17 Juli 2015 pada saat salat idul Fitri pada jam 07.00 waktu setempat. Korban jiwa terdiri sejumlah 12 orang luka-luka dan satu yang lalu korban meninggal dunia. Korban harta benda terdiri 13 kios dan satu musola terbakar. Pemerintah akan membangun kembali kios-kios dan musola yang terbakar $^{66}$. Hal tersebut pemerintah dan pemerintah daerah melaksanakan amanat undang-undang pada pemulihan pasca konflik melakukan (1) rekonsiliasi, (2) rehabilitasi dan (3) rekontruksi, yang kewajiban untuk melakukan upaya pemulihan pasca konflik secara terencana, terpadu, berkelanjutan, dan terukur.

\section{PENUTUP}

\section{SIMPULAN}

Berdasarkan uraian dan pembahasan, maka dapat disimpulkan sebagai berikut

1. Keanekaaragaman suku, agama, ras dan golongan merupakan modal yang memberikan kontribusi tegaknya NKRI dan sekaligus juga bisa menjadi potensi munculnya konflik serta munculnya konflik yang semakin besar, jika terjadi kesenjangan sosial, meskipun Indonesia sudah memiliki peraturan perundangan baik tertulis maupun tidak tertulis dalam menangani konflik sosial.

2. Perlindungan Korban akibat terjadinya konflik sosial terutama masyarakat sipil yang tidak berkonflik dengan kelompok masyarakat manapun telah diundangkan hukum nasional yaitu: Undang-undang No 7 tahun 2012 tentang konflik sosial dan juga telah mengundangkan peraturan pelaksanaanya, yaitu Peraturan Pemerintah Nomor: 12 tahun 2015 gtentang penanganan konflik sosial.

\footnotetext{
${ }^{66}$ www tempo/.../ Rusuh Tolikara ":Bentrok Tolikara, Pemerintah Janji Bangun Kios Yang dibakar". Diunduh tgl 26 Agt 2015
} 


\section{DAFTAR PUSTAKA}

Gosita, Arief, 1987, Victimologi dan KUHAP, Jakarta: Akademi Pressindo

Haryomataram, GPH, 1984, Hukum Humaniter, Jakarta: CV Rajawali,

Hermawan Pancasiwi, et al, 2013, Pemetaan Sumber dan Konflik di Wilayah Propinsi Jawa Tengah, Semarang: Laporan penelitian atas kerjasama antara Badan Kesbang Pol dan Linmas Propinsi Jawa Tengah dengan Fakultas Hukum dan Komunikasi Universitas Katolik Soegijapranata.

Muladi, 1988, Perlindungan Korban Melalui Proses Pemidanaan, Makalah disampaikan dalam seminar nasional Viktimologis: Penyelesaian permasalahan korban, Fak Hukum Unair, 28 -29 Oktober 1988.

Sahetapy, J E, 1987, Victimologi Sebuah Bunga Rampai, Jakarta: Pustaka Sinar Harapan

Soerjowinoto, Petrus, 2014, Pendidikan Kewarganegaraan Buku Panduan Mahasiswa, Semarang: LPPMKU Unika Soegijapranata.

Suharyono, et al, 2013, Penegakan Hukum di Daerah Konflik, Jakarta: Pusat penelitian dan Pengembangan Sistem Hukum Nasianal, Badan Pembinaan Hukum Nasioanal dan Hak Asasi Manusia Republik Indonesia

Republik Indonesia, Undang-undang Nomor: 26 Tahun 2000 Tentang Pengadilan Hak Asasi Manusia, Lembaran Negara Republik Indonesia Tahun 2000 Nomor 208

Republik Indonesia, Undang-undang Nomor: 7 Tahun 2012 Tentang Penanganan Konflik Sosial, Lembaran Negara Republik Indonesia tahun 2012 Nomor 116.

Peraturan Pemerintah Nomor: 2 Tahun 2015 tentang Peraturan Pelaksanaan Undangundang Nomor 7 tahun 2012 tentang Penanganan Konflik Sosial, Lembaran Negara Indonesia Tahun 2015 Nomor 25.

www tempo/.../ Rusuh Tolikara “:Bentrok Tolikara, Pemerintah Janji Bangun Kios Yang dibakar”. Diunduh tgl 26 Agt 2015 